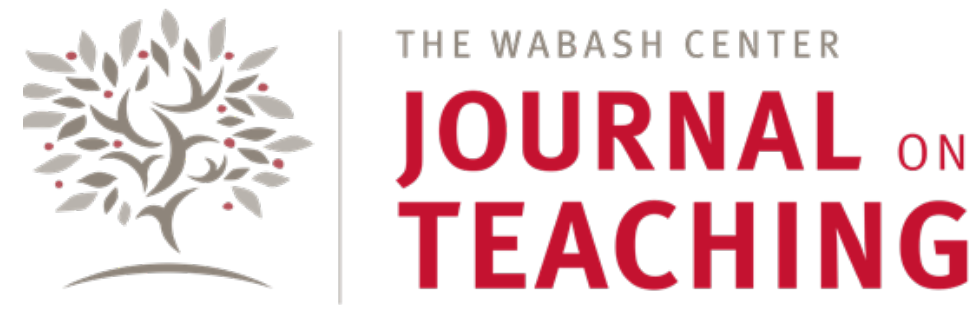

SPECIAL TOPIC

\title{
All Interpretations Are Subjective
}

\author{
Jocelyn McWhirter \\ Albion College
}

\begin{abstract}
This short essay describes a teaching strategy that addresses a key threshold concept in undergraduate biblical studies courses - how an interpreter's location within a particular tradition influences that interpreter's understanding of biblical texts about gender, sex, and sexuality. It is a companion essay to John Van Maaren's "Transformative Concepts and Troublesome Knowledge: Toward a Threshold Concept Framework for Biblical Studies," also published in this issue of the journal.
\end{abstract}

\section{KEYWORDS}

biblical studies, threshold concepts, feminist hermeneutics, biblical interpretation

John Van Maaren describes threshold concepts as gateways that students must pass through for further learning in a discipline (2019). In my upper-level course "Gender and Biblical Interpretation," I want students to learn how an interpreter's location within a particular tradition influences that interpreter's understanding of biblical texts about gender, sex, and sexuality. I therefore draw the course's main threshold concept from Mary Ann Tolbert's article "Defining the Problem: The Bible and Feminist Hermeneutics." Tolbert writes, "All interpretations are subjective, that is, all readings are influenced by the vested interests and concerns of the interpreter" (Tolbert 1983, 118; emphasis original).

Early in the course, I invite students to cross this threshold by assigning excerpts from her article. In class, I ask them to write (but not to share) a brief paragraph of a personal experience that made them think, "I don't belong here." They might reflect on being a Methodist in a Catholic high school or being Black in a historically white college. I then point out that such experiences highlight how we see the world differently from people who do "belong." The implication is clear: women (especially feminists) and men interpret the Bible differently, as do Jews and Christians, Protestants and Catholics, liberals and conservatives.

As the course progresses, we take care to define the traditions and social locations that influence each interpreter we encounter. Students discuss such questions as, "In what sense can Mary Ann Tolbert claim that the Bible is God's eternal Word?" "Most feminist scholars are highly-educated white women. To what extent can they speak for all women?" "Contrast Conservative Rabbi Howard Handler's conclusions about the halakha of homosexual relationships with those of Orthodox Rabbi Nachum Amsel. How would you describe Amsel's hermeneutic? How would you describe Handler's approach?" "Compare the interpretations of Charles Ryrie and Jane Schaberg concerning Mary and motherhood with those of Pope Paul VI." For the last question of the final exam, students explain their agreement or disagreement with Tolbert's statement that "all interpretations are subjective" $(1983,118)$ and describe what their standpoint implies about the objective truth of the Bible. 
Sociologists Christian Smith and Patricia Snell write that "most emerging adults in the United States today" agree that "everybody's different” and "all cultures are relative" (Smith and Snell 2009, 48-51). I have found this to be true for my students. Since most have already crossed this threshold with regard to their personal beliefs, it is easy for them to cross it with regard to biblical interpretation. It is more challenging for them to see that, in doing so, they have entered a world in which John Van Maaren and Mary Ann Tolbert can say, "Everything is an argument," and, "All hermeneutical perspectives are advocacy positions" (Van Maaren 2020, 61-78; Tolbert 1983, 118). The next time I teach "Gender and Biblical Interpretation," I will try some new strategies for opening students' eyes.

\section{BIBLIOGRAPHY}

Smith, Christian, and Patricia Snell. 2009. Souls in Transition: The Religious and Spiritual Lives of Emerging Adults. New York, NY: Oxford University Press.

Tolbert, Mary Ann. 1983. “Defining the Problem: The Bible and Feminist Hermeneutics.” Semeia 28: 113-26.

Van Maaren, John. 2020. "Transformative Concepts and Troublesome Knowledge: Toward a Threshold Concept Framework for Biblical Studies." The Wabash Center Journal on Teaching 1(1): 61-78. https://doi.org/10.31046/wabashjournal.vii1.1526.

\section{ABOUT THE AUTHOR}

Jocelyn McWhirter is the Stanley S. Kresge Professor of Religious Studies at Albion College in Albion, Michigan, where she directs The Newell Center for Teaching and Learning. She holds a PhD in New Testament Studies from Princeton Theological Seminary. 